\title{
Inhibitory effect of Artemisia capillaris extract on cytokine-induced nitric oxide formation and cytotoxicity of RINm5F cells
}

\author{
EUN-KYUNG KIM ${ }^{1 *}$, KANG-BEOM KWON $^{2 *}$, MI-JEONG HAN ${ }^{1}$, MI-YOUNG SONG ${ }^{1}$, JI-HYUN LEE $^{1}$, NA LV $^{1}$, \\ KI-BANG CHOI ${ }^{2}$, DO-GON RYU ${ }^{2}$, KANG-SAN KIM ${ }^{3}$, JIN-WOO PARK ${ }^{1}$ and BYUNG-HYUN PARK ${ }^{1}$ \\ ${ }^{1}$ Department of Biochemistry, Medical School, Chonbuk National University, Jeonju, Jeonbuk 561-756, Korea \\ Departments of ${ }^{2}$ Physiology, ${ }^{3}$ Internal Medicine, School of Oriental Medicine, \\ Won-Kwang University, Iksan, Jeonbuk 570-749, Korea
}

Received November 21, 2006; Accepted December 27, 2006

\begin{abstract}
Cytokines produced by immune cells infiltrating pancreatic islets are important mediators of B-cell destruction in insulin-dependent diabetes mellitus. Cytokines stimulate an inducible form of nitric oxide synthase (iNOS) expression and nitric oxide (NO) production, leading to insulin insufficiency. In the present study, the effects of Artemisia capillaris extract (ACE) on cytokine-induced B-cell damage were examined. Treatment of RINm5F (RIN) rat insulinoma cells with interleukin-1ß (IL-1ß) and interferon- $\gamma($ IFN- $\gamma$ ) induced cell damage. ACE completely protected IL-1B and IFN- $\gamma$-mediated cytotoxicity in a concentration-dependent manner. Incubation with ACE resulted in a significant reduction in IL-1B and IFN- $\gamma$-induced NO production, a finding that correlated well with reduced levels of the iNOS mRNA and protein. The molecular mechanism by which ACE inhibited iNOS gene expression appeared to involve the inhibition of NF- $\kappa \mathrm{B}$ activation. The IL-1ß and IFN $-\gamma-$ stimulated RIN cells showed increases in NF- $\mathrm{KB}$ binding activity and p65 subunit levels in the nucleus, and IкB $\alpha$ degradation in cytosol compared to unstimulated cells. Furthermore, ACE restored the cytokine-induced inhibition of insulin release from isolated islets. These results suggest that $\mathrm{ACE}$ protects $\beta$-cells by suppressing NF- $\mathrm{\kappa B}$ activation.
\end{abstract}

\section{Introduction}

Type 1 diabetes mellitus is an autoimmune disease causing selective destruction of insulin-producing $\beta$-cells of the

Correspondence to: Dr Byung-Hyun Park, Department of Biochemistry, Chonbuk National University, Medical School, Jeonju, Jeonbuk 561-756, Korea

E-mail: bhpark@chonbuk.ac.kr

${ }^{*}$ Contributed equally

Key words: Artemisia capillaris, ß-cell, cytokine, nuclear factor$\kappa \mathrm{B}$, nitric oxide
Langerhans islets (1). Evidence supports a crucial role for infiltrated immune cells in and around pancreatic islets early in pathogenesis $(2,3)$. In an activated state, T-lymphocytes and macrophages, the primary cellular components of islet insulitis, release high levels of interleukin (IL)-1ß and interferon (IFN)- $\gamma$, respectively. IL-1ß alone, or in combination with tumor necrosis factor (TNF)- $\alpha$ or IFN- $\gamma$, causes the production of excess nitric oxide (NO) by the inducible form of nitric oxide synthase (iNOS) in pancreatic islets (4-6). Nitric oxide is a short-lived and highly reactive radical, which inhibits the Krebs-cycle enzyme aconitase and the electron transport chain complexes I and II leading to decreased glucose oxidation rates, ATP generation and insulin production (7-9). Heitmeier et al (10) demonstrated that IL-1ß-induced inhibition of insulin secretion and nitrite production by rat islets was completely prevented by $\mathrm{N}^{\mathrm{w}}$ nitro-L-arginine methylester (L-NAME) and aminoguanidine.

The transcriptional nuclear factor $\kappa \mathrm{B}(\mathrm{NF}-\kappa \mathrm{B})$ has been implicated as a key signaling mediator for IL-1B and has been proposed to regulate transcription of the iNOS gene $(5,11)$. NF- $\mathrm{KB}$ is initially located in the cytoplasm as an inactive form complexed with $\mathrm{I \kappa B}$, an inhibitory factor of $\mathrm{NF}-\kappa \mathrm{B}$. Various inducers cause dissociation of this complex,

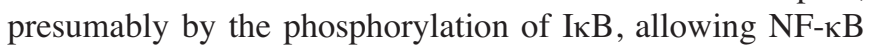
to be released from the complex. NF- $\mathrm{KB}$ then translocates to the nucleus, where it interacts with its DNA recognition sites to mediate gene transcription $(12,13)$.

Artemisia capillaris is the young plant of Artemisia capillaris $\mathrm{T}_{\mathrm{HUNB}}$ and belongs to the family of Compositae. It has been used to remove fever, to dispel dampness, and to relieve jaundice in traditional oriental medicine. Hong et al reported that ACE inhibited lipopolysaccharide-induced inflammatory response through suppression of NF- $\mathrm{KB}$ activation (14). To our knowledge, the antidiabetic effects of Artemisia capillaris have not yet been reported. In the present study, we investigated the feasibility of Artemisia capillaris as a means of preventing IL- $1 \beta$ and IFN- $\gamma$-induced $\beta$-cell destruction. Artemisia capillaris extract inhibited IL$1 \mathrm{~B}$ and IFN- $\gamma$-induced NF-кB activation, iNOS expression, NO formation, glucose-stimulated insulin secretion (GSIS) 
and the cell death of $\beta$-cells, demonstrating the beneficial effects of Artemisia capillaris as an antidiabetic agent.

\section{Materials and methods}

Cell culture. RINm5F (RIN) cells were purchased from the American Type Culture Collection and grown at $37^{\circ} \mathrm{C}$ under a humidified 5\% $\mathrm{CO}_{2}$ atmosphere in RPMI-1640 medium (Gibco BRL) supplemented with $10 \%$ fetal bovine serum and $2 \mathrm{mM}$ glutamine, 100 units $/ \mathrm{ml}$ of penicillin, $100 \mu \mathrm{g} / \mathrm{ml}$ of streptomycin, and $2.5 \mu \mathrm{g} / \mathrm{ml}$ of amphotericin B.

Preparation of Artemisia capillaris extract (ACE). For extraction, $200 \mathrm{~g}$ of Artemisia capillaris was ground and extracted with boiling water for $4 \mathrm{~h}$. After centrifugation at $3,000 \mathrm{x} \mathrm{g}$ for $20 \mathrm{~min}$, the supernatant was concentrated under reduced pressure to $200 \mathrm{ml}$ and freeze dried to $23.4 \mathrm{~g}$. The sterile extract was stored at $-70^{\circ} \mathrm{C}$.

MTT assay for cell viability. The viability of cultured cells was determined by assaying for the reduction of 3-(4,5dimethylthiazol-2-yl)-2,5-diphenyltetrazolium bromide (MTT) to formazan as described previously (15). In brief, after $48 \mathrm{~h}$ of incubation, cells (104/well) in 96-well plates were washed twice with PBS. MTT $(100 \mu \mathrm{g} / 0.1 \mathrm{ml}$ of PBS) was added to each well. Cells were incubated at $37^{\circ} \mathrm{C}$ for $1 \mathrm{~h}$, and DMSO $(100 \mu \mathrm{l})$ was added to dissolve the formazan crystals. The absorbance was measured at $570 \mathrm{~nm}$ with a model SpectraMax Plus spectrophotometer (Molecular Devices, Sunnyvale, CA).

5-Bromo-2-deoxyuridine (BrdU)-labeling cell proliferation assay. A cell proliferation enzyme-linked immunosorbent assay (BrdU kit; Amersham Biosciences, Piscataway, NJ) was used to measure the incorporation of BrdU during DNA synthesis according to the manufacturer's protocol. Briefly, cells were seeded overnight in 96-well tissue culture plates with clear, flat bottoms (Becton Dickinson, Franklin Lakes, $\mathrm{NJ})$ at a density of $10^{5}$ cells per well in $100 \mu 1$ of medium. Cells were treated with a range of concentrations for $48 \mathrm{~h}$. $\operatorname{BrdU}(10 \mu \mathrm{M})$ was added to the culture medium for $2 \mathrm{~h}$, the BrdU-labeled cells were fixed, and the DNA was denatured in fixative solution for $30 \mathrm{~min}$ at room temperature. Cells were incubated with peroxidase-conjugated anti-BrdU antibody for $2 \mathrm{~h}$ at room temperature and washed three times with washing solution. The immune complex was detected by the 3,3',5,5'-tetramethylbenzidine substrate reaction and the absorbance was measured at $405 \mathrm{~nm}$ with a SpectraMax Plus spectrophotometer.

Nitrite measurement. Biologically produced NO is rapidly oxidized to nitrite and nitrate in aqueous solutions (16). Nitrite concentrations in the cell-free culture supernatant, therefore, served as a reflection of NO production and were measured using a colorimetric assay (17). Following a 48-h incubation, 100- $\mu 1$ aliquots of the culture supernatants were incubated with $100 \mu \mathrm{l}$ of a $1: 1$ mixture of $1 \%$ sulfanilamide in $30 \%$ acetic acid and $0.1 \% \mathrm{~N}$-(1-naphthyl) ethylenediamine dihydrochloride in $60 \%$ acetic acid at room temperature. After $5 \mathrm{~min}$, the absorbance was measured at $540 \mathrm{~nm}$ using a
Table I. Sequences and accession numbers for primers, forward and reverse, used in real-time PCR.

\begin{tabular}{llc}
\hline Gene & \multicolumn{1}{c}{ Sequence for primers } & $\begin{array}{c}\text { Accession } \\
\text { no. }\end{array}$ \\
\hline B-actin & $\begin{array}{l}\text { Forward: GTGCTATGTTGCTCTAGACT } \\
\text { Reverse: CACAGGATTCCATACCCAAG }\end{array}$ & NM 007393 \\
iNOS & $\begin{array}{l}\text { Forward: GTTCTTTGCTTCTGTGCTAAT } \\
\text { Reverse: GTGTTTGCCTTATACTGTTCCA }\end{array}$ & D 44591 \\
\hline
\end{tabular}

SpectraMax Plus spectrophotometer. Concentrations of NO were determined from a linear standard curve obtained from serial dilutions of sodium nitrite in working medium.

RNA isolation and real-time PCR for iNOS. Total RNA was isolated from RIN cells using TRIzol reagent (Life Technologies Ltd, UK). RNA was precipitated with isopropanol, dissolved in DEPC-treated distilled water and kept at $-80^{\circ} \mathrm{C}$ until use. One $\mu \mathrm{g}$ of RNA was reverse transcribed with SuperScript II reverse transcriptase (Life Technologies Ltd). The cDNA was diluted 10-fold prior to PCR amplification. Real-time PCR was performed using the LightCycler rapid thermal cycler system (Roche Diagnostics Ltd, UK) according to the manufacturer's instructions. Specific primers for each gene (Table I) were designed using LightCycler software 4 . The real-time PCR contained, in a final volume of $20 \mu \mathrm{l}, 100 \mathrm{ng}$ of reverse transcribed total RNA, $500 \mathrm{nM}$ of the forward and reverse primers, and $14 \mu \mathrm{l}$ of 2X SYBR-Green buffer (Roche). PCR amplification began with a 10 -min preincubation step at $95^{\circ} \mathrm{C}$, followed by 45 cycles of denaturation at $95^{\circ} \mathrm{C}$ for $10 \mathrm{sec}$, annealing at $58^{\circ} \mathrm{C}$ (iNOS) or $63^{\circ} \mathrm{C}$ (ß-actin) for $5 \mathrm{sec}$, and elongation at $72^{\circ} \mathrm{C}$ for $10 \mathrm{sec}$. The relative concentrations of PCR product derived from the target gene (iNOS) were calculated using the LightCycler System software. Results were expressed relative to the number of $B$-actin transcripts used as an internal control. All experiments were performed in triplicate.

Western blot analysis. Cells were homogenized in $100 \mu 1$ of ice-cold lysis buffer (20 mM HEPES, pH 7.2, 1\% Triton $\mathrm{X}-100,10 \%$ glycerol, $1 \mathrm{mM}$ phenylmethylsulfonylfluoride, $10 \mu \mathrm{g} / \mathrm{ml}$ leupeptin, and $10 \mu \mathrm{g} / \mathrm{ml}$ aprotinin). The homogenates containing $20 \mu \mathrm{g}$ of protein were separated by SDSPAGE with $10 \%$ acrylamide resolving and 3\% stacking gels, and were transferred to nitrocellulose sheets in a Western blot apparatus (Bio-Rad, Hercules, CA). The nitrocellulose paper was blocked with $2 \%$ bovine serum albumin and then incubated for $4 \mathrm{~h}$ with $1 \mu \mathrm{g} / \mathrm{ml}$ of primary antibodies for iNOS, IкB $\alpha$, ІкBß, or p65 (Santa Cruz Biochemicals, Santa Cruz, CA). Horseradish peroxidase-conjugated IgG (Zymed, San Francisco, CA) was used as secondary antibody. Protein expression levels were determined by analyzing the signals captured on the nitrocellulose membranes using a ChemiDoc image analyzer (Bio-Rad).

Preparation of nuclear extracts. Nuclear extracts were prepared as described previously (18). Cells were immediately 
(A)

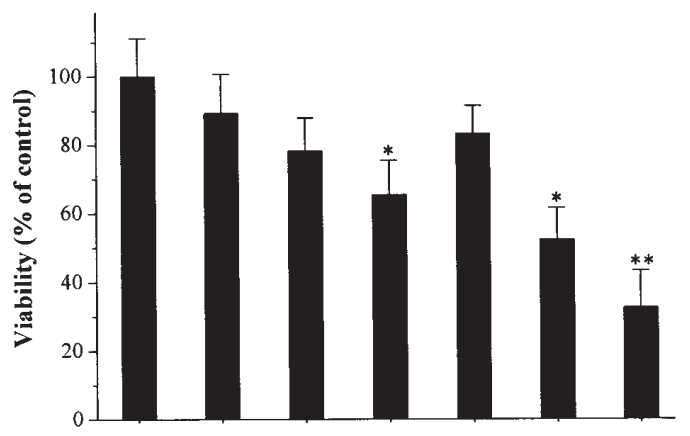

(B)

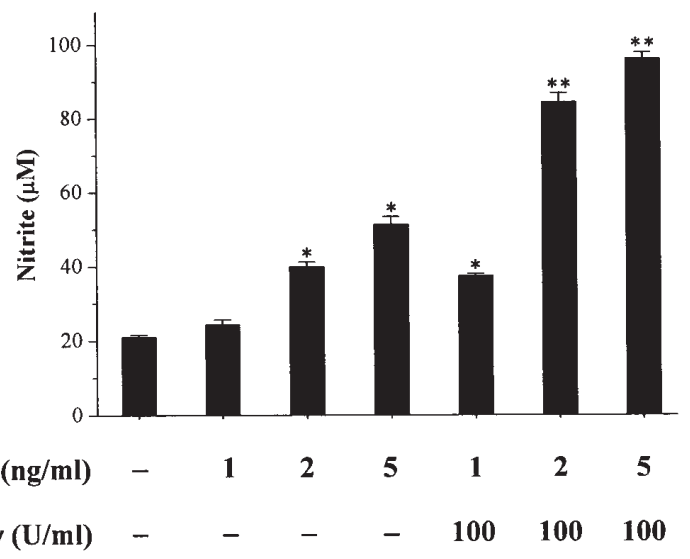

Figure 1. Cytokine-induced viability, and NO production in RIN cells. (A) RIN cells $\left(1 \times 10^{5}\right)$ were incubated with IL-1ß alone or in combination with IFN- $\gamma$ as indicated. The percentage of cells viable after these treatments was determined by the MTT colorimetric assay and calculated as a ratio of $\mathrm{A}_{570}$ of treated and control cells (treated with $0.05 \%$ DMSO vehicle). (B) Cells $\left(4 \times 10^{5}\right)$ were treated with the cytokines for $48 \mathrm{~h}$ and the nitrite concentration was measured in the cell-free culture supernatants as a reflection of NO synthesis. Results of triplicate samples were expressed as mean \pm SEM. ${ }^{*} \mathrm{P}<0.05,{ }^{* *} \mathrm{P}<0.01$ vs. untreated control.

washed twice, scraped into $1.5 \mathrm{ml}$ of ice-cold PBS (pH 7.9), and pelleted at $12,000 \mathrm{x}$ g for $30 \mathrm{sec}$. The cell pellets were suspended in ice-cold hypotonic lysis buffer (10 mM HEPES, $1.5 \mathrm{mM} \mathrm{MgCl}_{2}, 0.2 \mathrm{mM} \mathrm{KCl}, 0.2 \mathrm{mM}$ phenylmethylsulfonylfluoride, $0.5 \mathrm{mM}$ dithiothreitol), vortexed for $10 \mathrm{sec}$ and then centrifuged at 3,000 rpm for 5 min. The packed cells were re-suspended with ice-cold hypotonic lysis buffer in the presence of $50 \mu 1$ of $10 \%$ Nonidet P-40 and then incubated on ice for $25 \mathrm{~min}$. The nuclear fractions were precipitated by centrifugation at 4,000 rpm for $15 \mathrm{~min}$. IкB $\alpha$ and IкBß were analyzed in the cytoplasmic fractions by Western blotting. The pelleted nuclei were re-suspended in 50-100 $\mu 1$ of low salt extraction buffer (20 mM HEPES, pH 7.9, $1.5 \mathrm{mM}$ $\mathrm{MgCl}_{2}, 25 \%$ glycerol, $20 \mathrm{mM} \mathrm{KCl}, 0.2 \mathrm{mM}$ EDTA, $0.2 \mathrm{mM}$ phenylmethylsulfonylfluoride and $0.5 \mathrm{mM}$ dithiothreitol) and added to equal volumes of high salt extraction buffer $(20 \mathrm{mM}$ HEPES, pH 7.9, $1.5 \mathrm{mM} \mathrm{MgCl}_{2}, 25 \%$ glycerol, $80 \mathrm{mM} \mathrm{KCl}$, $0.2 \mathrm{mM}$ EDTA, $0.2 \mathrm{mM}$ phenylmethylsulfonylfluoride, and $0.5 \mathrm{mM}$ dithiothreitol) in a drop-wise fashion, and then incubated under continuous shaking at $4^{\circ} \mathrm{C}$ for $45 \mathrm{~min}$. The samples were centrifuged for $20 \mathrm{~min}$ at $12,000 \mathrm{x} \mathrm{g}$. Aliquots of the nuclear extracts were stored at $-80^{\circ} \mathrm{C}$. Protein concentration was determined by the method of Bradford (19).

Electrophoretic mobility shift assay (EMSA). The activation of NF- $\mathrm{KB}$ was assayed by a gel mobility shift assay using
(A)

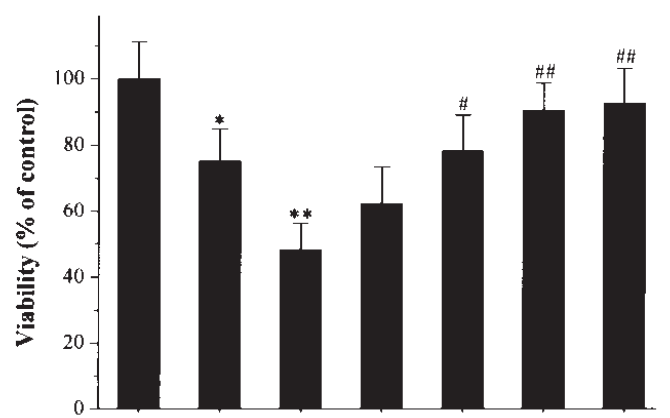

(B)

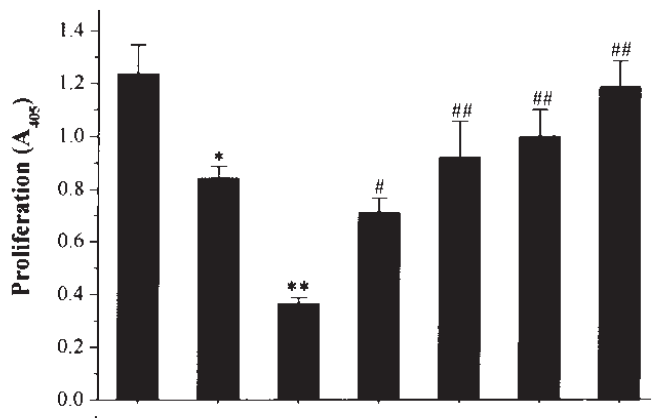

(C)

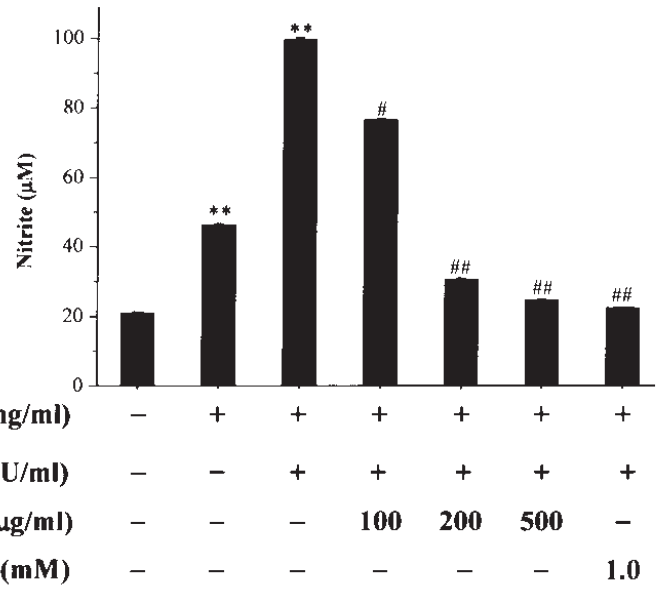

Figure 2. Prevention of cytokine-induced cell death and NO production by ACE. RIN cells were incubated with cytokines in the presence or absence of ACE or L-NAME for $48 \mathrm{~h}$ as indicated. The cell viability (A), proliferation capacity (B) and NO production (C) were determined. Each value is the mean \pm SEM of four independent experiments. ${ }^{*} \mathrm{P}<0.05,{ }^{* *} \mathrm{P}<0.01 \mathrm{vs}$. control; ${ }^{\mathrm{P}}<0.05,{ }^{\# \#} \mathrm{P}<0.01$ vs. IL- $1 \beta+\mathrm{IFN}-\gamma$.

nuclear extracts from control and treated cells. As a probe for the gel retardation assay, an oligonucleotide containing the $\kappa$ chain binding site $\left(\kappa \mathrm{B}, 5^{\prime}\right.$-CCGGTTAACAGAGGGGGCTT TCCGAG-3') was synthesized. The two complementary strands were annealed and labeled with $\left[\alpha-{ }^{32} \mathrm{P}\right] \mathrm{dCTP}$. Labeled oligonucleotides $(10,000 \mathrm{cpm}), 10 \mu \mathrm{g}$ of nuclear extracts, and binding buffer ( $10 \mathrm{mM}$ Tris- $\mathrm{HCl}, \mathrm{pH} 7.6,500 \mathrm{mM}$ $\mathrm{KCl}, 10 \mathrm{mM}$ EDTA, 50\% glycerol, $100 \mathrm{ng}$ poly $(\mathrm{dI} \cdot \mathrm{dC})$ and $1 \mathrm{mM}$ DTT) were incubated for $30 \mathrm{~min}$ at room temperature in a final volume of $20 \mu 1$. The reaction mixtures were analyzed by electrophoresis on $4 \%$ polyacrylamide gels in $0.5 \mathrm{X}$ Tris-borate buffer. The gels were dried and examined by autoradiography. Specific binding was controlled by competition with a 50-fold excess of cold $\mathrm{\kappa B}$ oligonucleotide.

Isolation of islets. Pancreatic islets were isolated from male Sprague-Dawley rats by collagenase digestion as described 


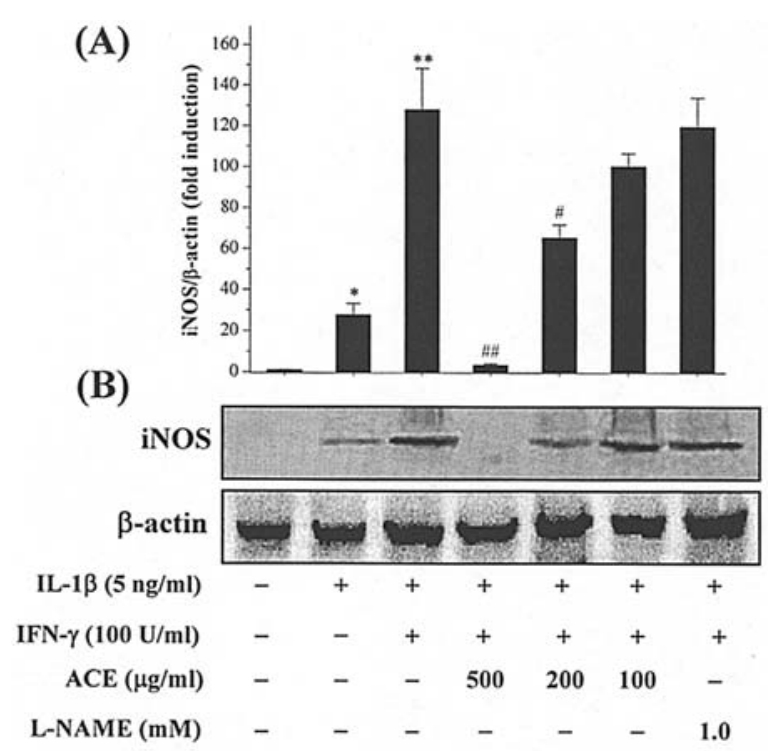

Figure 3. Inhibition of cytokine-induced iNOS expression by ACE. RIN cells $\left(5 \times 10^{6}\right)$ were incubated with IL-1ß $(5 \mathrm{ng} / \mathrm{ml})$ and/or IFN- $\gamma(100 \mathrm{U} / \mathrm{ml})$ in the presence or absence of ACE $(500 \mu \mathrm{g} / \mathrm{ml})$ or L-NAME $(1 \mathrm{mM})$ for $48 \mathrm{~h}$. Real time-PCR (A) and Western blot analysis (B) for iNOS were performed as described in 'Materials and methods'. A representative result was determined from among at least three separate experiments with similar results. ${ }^{*} \mathrm{P}<0.05,{ }^{* *} \mathrm{P}<0.01$ vs. control; ${ }^{\#} \mathrm{P}<0.05,{ }^{\# \#} \mathrm{P}<0.01$ vs. IL- $1 \beta+\mathrm{IFN}-\gamma$.

previously (20). Following isolation, the islets were cultured overnight in RPMI-1640 (RPMI-1640 containing 2 mM Lglutamine, $10 \%$ heat-inactivated fetal calf serum, 100 units/ $\mathrm{ml}$ penicillin, and $100 \mu \mathrm{g} / \mathrm{ml}$ streptomycin) in an atmosphere of $95 \% \mathrm{O}_{2}$ and $5 \% \mathrm{CO}_{2}$ at $37^{\circ} \mathrm{C}$. Prior to each experiment, the islet cells were washed three times in RPMI-1640, counted and then cultured overnight.

Insulin secretion assay. The islets were cultured for $24 \mathrm{~h}$ with cytokines in the presence or absence of ACE. The islets were washed three times in Krebs-Ringer bicarbonate buffer (25 mM HEPES, $115 \mathrm{mM} \mathrm{NaCl}, 24 \mathrm{mM} \mathrm{NaHCO}, 5 \mathrm{mM}$ $\mathrm{KCl}, 1 \mathrm{mM} \mathrm{MgCl}_{2}, 2.5 \mathrm{mM} \mathrm{CaCl}_{2}$, and $0.1 \%$ bovine serum albumin, $\mathrm{pH}$ 7.4) containing $3 \mathrm{mM}$ D-glucose, and insulin secretion assays were performed in the presence of either 5.5 or $20 \mathrm{mM}$ D-glucose. The insulin content of the medium was determined by ELISA (21).

Statistical analysis. Statistical analysis of the data was performed with the Student's t-test and ANOVA. Differences of $\mathrm{P}<0.05$ were considered statistically significant.

\section{Results}

Prevention of cytokine-induced cell death by ACE. We initially evaluated the optimal conditions to observe the effect of cytokines on the viability of $\beta$-cells. The rat pancreatic $\beta$-cell line RIN was cultured to near confluence. Using a single-dose IL- 13 or a combination of IL- 13 and IFN- $\gamma$, we treated RIN cells with or without ACE for $48 \mathrm{~h}$, at which time the cells were harvested and their viability was analyzed. A single treatment with IL-1ß decreased the viability in a dosedependent manner, whereas a combination of IL- $1 \beta$ and IFN- $\gamma$

\begin{tabular}{|c|c|c|c|c|c|c|}
\hline $\mathrm{IL}-1 \beta(5 \mathrm{ng} / \mathrm{ml})$ & + & - & + & + & + & + \\
\hline IFN- $\gamma(100 \mathrm{U} / \mathrm{ml})$ & + & - & + & + & + & + \\
\hline $\operatorname{ACE}(\mu \mathrm{g} / \mathrm{ml})$ & - & - & - & 100 & 200 & 500 \\
\hline Cold-кB & + & - & - & - & - & - \\
\hline
\end{tabular}

(A)

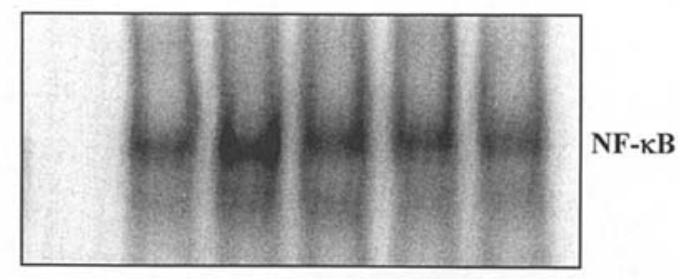

(B)
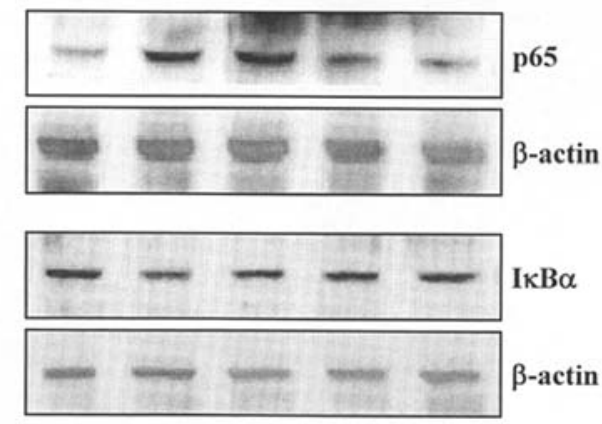

Figure 4. Inhibition of cytokine-stimulated translocation of $\mathrm{NFKB}$ to the nucleus and IкB $\alpha$ degradation by ACE. RIN cells $\left(5 \times 10^{6}\right)$ were treated with IL-1B $(5 \mathrm{ng} / \mathrm{ml})$ and IFN- $\gamma(100 \mathrm{U} / \mathrm{ml})$ in the presence or absence of ACE. Following a 30-min incubation, NF- $\mathrm{kB}$ translocation was analyzed by EMSA (A), and the p65 expression and IкB $\alpha$ degradation (B) were determined by Western blotting.

$(100 \mathrm{U} / \mathrm{ml})$ caused a significant reduction in cell viability (Fig. 1A). In contrast, ACE increased the viability of IL-1ß and IFN- $\gamma$-treated RIN cells in a concentration-dependent manner (Fig. 2A). The protective effect of ACE on IL-1B and IFN- $\gamma$-induced cytotoxicity was further confirmed using BrdU incorporation in RIN cells. BrdU is a thymidine analog that is incorporated into proliferating cells during DNA synthesis; thus it reflects the proliferative potential of the cells. IL-1ß and IFN- $\gamma$ reduced the level of BrdU incorporation, hence proliferation, at 48 -h incubations to $29.5 \pm 1.8 \%$ of control levels (Fig. 2B). Similar to the MTT assay data, ACE restored the cell proliferation potential with an increasing concentration (Fig. 2B). ACE alone did not affect the viability even at a higher concentration $(1 \mathrm{mg} / \mathrm{ml})$ (data not shown).

Effect of ACE on IL-1 $\beta$ and IFN- $\gamma$-induced NO production by RIN cells. It has been reported that IL- $1 \beta$ and IFN- $\gamma$-mediated destruction of $\beta$-cells is caused by an increase in NO production $(6,11,22)$. Incubation of RIN cells with IL-1ß and IFN- $\gamma$ for $48 \mathrm{~h}$ resulted in a significant production of nitrite (a stable oxidized product of NO) by these cells (Fig. 1B). Cells preincubated with L-NAME (1 $\mathrm{mM})$ exhibited complete resistance against IL- $1 \beta$ and IFN- $\gamma$-mediated killing as expected (Fig. 2). Comparatively, ACE (500 $\mu \mathrm{g} / \mathrm{ml})$ increased the viability and decreased the nitrite production of IL-1B and IFN- $\gamma$-treated RIN cells to $90.3 \pm 8.3 \%$ and $24.7 \pm 0.2 \mu \mathrm{M}$, respectively (Fig. 2). To examine whether ACE inhibited NO production via suppression of iNOS gene expression, the changes in iNOS mRNA and protein were investigated by real time-PCR and Western blot analysis, respectively. Cells treated with IL-1ß alone slightly increased iNOS mRNA 


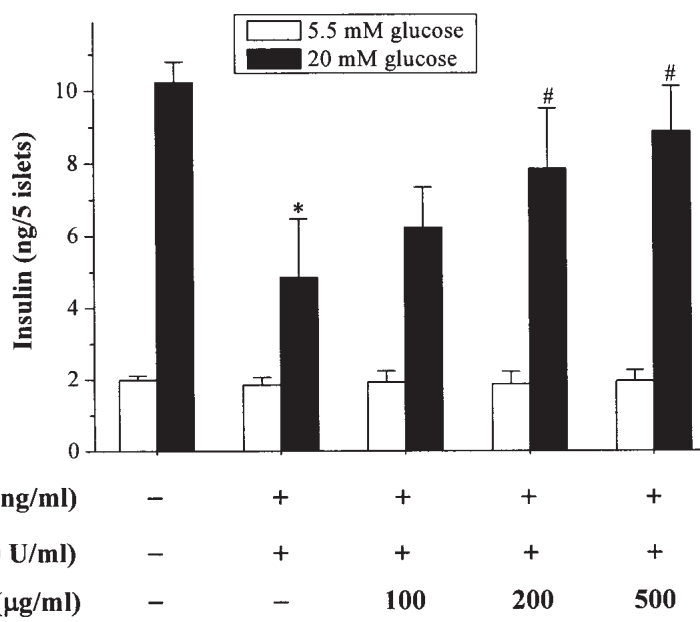

Figure 5. Effects of ACE on IL-1ß and IFN- $\gamma$-induced inhibition of glucosestimulated insulin secretion. Rat islets ( 5 islets $/ 500 \mu 1$ ) were treated with IL$1 \beta(5 \mathrm{ng} / \mathrm{ml})$ and IFN- $\gamma(100 \mathrm{U} / \mathrm{ml})$ in the presence or absence of ACE for $24 \mathrm{~h}$. Following the incubation period, GSIS was assayed as described in 'Materials and Methods'. Results of triplicate samples were expressed as mean \pm SEM. ${ }^{*} \mathrm{P}<0.05$ vs. untreated control; ${ }^{\#} \mathrm{P}<0.05$ vs. IL- $1 \beta+\mathrm{IFN}-\gamma$.

and $130-\mathrm{kDa}$ iNOS protein expression, whereas marked increases of iNOS mRNA and protein were observed in cells treated with IL-1ß and IFN- $\gamma$ (Fig. 3). Cells pretreated with ACE at a concentration of $500 \mu \mathrm{g} / \mathrm{ml}$ showed suppressed expression of iNOS in both their mRNA and protein levels in a concentration-dependent manner (Fig. 3). These results indicate that IL-1ß and IFN- $\gamma$-induced NO production was caused by the iNOS expression in the RIN cells.

Effect of ACE on IL-1 $\beta$ and IFN- $\gamma$-induced $N F-\kappa B$ activation. $\mathrm{NF}-\kappa \mathrm{B}$ is implicated in the transcriptional regulation of cytokine-induced iNOS expression. Thus, we studied the effect of ACE on cytokine-stimulated translocation of NF- $\mathrm{KB}$ from the cytoplasmic compartment to the nucleus in RIN cells. The IL-1ß and IFN- $\gamma$-stimulated RIN cells showed increases in NF- $\mathrm{B}$ binding activity and p65 subunit levels in their nucleus (Fig. 4A and $\mathrm{B}$ ) and $\mathrm{I} \kappa \mathrm{B} \alpha$ degradation in the cytosol (Fig. 4B) when compared to unstimulated cells. IкBß was not affected by IL- $1 B$ and IFN- $\gamma$ treatment (data not shown). IL-1ß and IFN- $\gamma$-induced NF- $\kappa$ B activation and IкB $\alpha$ degradation were markedly suppressed by the addition of ACE, which suggests that ACE inhibits iNOS expression through the inhibition of NF-кB activation. Specificity of the DNA-protein interactions for $\mathrm{NF}-\kappa \mathrm{B}$ was demonstrated by competition assays using a 50-fold excess of unlabeled oligonucleotide (Fig. 4A, lane 1).

Preservation of GSIS by ACE in the presence of $I L-1 \beta$ and $I F N-\gamma$. We assayed GSIS using rat pancreatic islets isolated from the male Sprague-Dawley rat to support the physiological importance of the results observed in the cell line studies (Fig. 5). After a 24-h exposure to IL-1ß and IFN- $\gamma$, insulin secretion in response to $20 \mathrm{mM}$ glucose was observed. Control islets secreted insulin at a concentration of $10.2 \pm 0.6 \mathrm{ng} / \mathrm{ml}$, whereas insulin secretion from IL-1B and IFN- $\gamma$-treated cells was significantly decreased to $4.8 \pm 1.6 \mathrm{ng}$ $/ \mathrm{ml}(\mathrm{P}<0.05)$. Pretreatment with ACE blocked the IL-1ß and
IFN- $\gamma$ effect and restored islet insulin secretion to near control levels. ACE alone did not affect insulin release compared to control (data not shown).

\section{Discussion}

Cytokines, as humoral mediators of inflammation, confer destruction to pancreatic $\beta$-cells of various species, including the rat and the human $(5,11)$. It has been previously shown that, whereas IL-1ß is a sufficient stimulus for induction of iNOS mRNA expression and NO production in RIN cells, a combination of IL-1B and IFN- $\gamma$ is required to induce NO formation by human islets $(4,5,10,23)$. The increased toxicity of the cytokine combination compared with that of IL-1ß alone (Fig. 1) was due to a significantly higher rate of iNOS mRNA and protein expression (Fig. 3) and subsequent NO production (Fig. 1B). Data obtained in other cell types suggest that putative sites for IFN- $\gamma$ action include stabilization of iNOS mRNA (24), potentiation of IL-1ß-induced $\mathrm{NF}-\kappa \mathrm{B}$ activation (25), and induction of other nuclear transcription factors, such as interferon regulatory factor-1 (26).

The central role of $\mathrm{NO}$ in cytokine-mediated $B$-cell toxicity prompted us to examine whether the protective effect of ACE was associated with modulation of NO levels. We found that ACE abrogated NO production in response to cytokines. Taken together with our current data showing that pharmacologic suppression of NO production by L-NAME, an iNOS inhibitor, also protects RIN cells from cytokine toxicity, our results establish the suppression of NO production as a critical mechanism by which ACE protects $B$ cells. The mechanism by which ACE suppresses cytokineinduced NO production was shown to be via the inhibition of cytokine-induced iNOS mRNA and protein expression (Fig. 3). Expression of iNOS protein in islets is regulated by de novo transcription of the iNOS gene (4-6), indicating that ACE regulates iNOS expression at the level of gene transcription.

Since NF-кB is the major transcription factor responsible for de novo activation of iNOS transcription by cytokines, we examined the effect of ACE on NF-kB activation. We found that ACE suppressed the activation of the transcription factor NF-кB in RIN cells. We have previously shown that herbs and dietary supplements protect $\beta$-cells from cytokine or cytotoxin toxicity through suppression of iNOS expression $(6,18,27,28)$. Many other groups have also tried to save $\beta$ cells from these insults by repressing either NF- $\kappa \mathrm{B}$ activation or NF-кB-dependent iNOS expression (29-32). Thus, repression of NF- $\mathrm{NB}$ or its downstream iNOS expression are important targets for protecting $\beta$-cells. NF- $\mathrm{KB}$ is a ubiquitous transcription factor constitutively expressed in the cytoplasm in an inactive form associated with an inhibitory protein termed IкB $(12,13)$. Cellular activation by inflammatory stimuli such as cytokines results in the phosphorylation and subsequent degradation of $\mathrm{I} \kappa \mathrm{B} \alpha$, thus allowing $\mathrm{NF}-\kappa \mathrm{B}$ to translocate into the nucleus and activate target genes such as iNOS $(12,13)$. Therefore, we examined the effect of ACE on $\mathrm{I} \kappa \mathrm{B} \alpha$ degradation. Our data demonstrate that ACE interferes

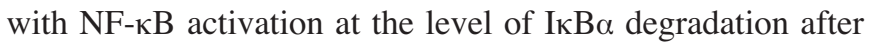
cytokine stimulation.

In summary, we demonstrated the potent inhibitory effect of ACE on cytokine-induced $\beta$-cell damage using an 
insulinoma cell line and isolated pancreatic islets. ACE rescued $B$-cells from cytokine toxicity, reversed impairment, and completely restored function. No other report has yet documented the application of ACE in the prevention of Bcell damage against cytokine toxicity. The results of this study will provide valuable information for both elucidating the mechanisms of autoimmune $\beta$-cell destruction and for developing drugs to combat type 1 diabetes.

\section{Acknowledgements}

This study was supported by the Regional Research Center Program of the Korean Ministry of Education and Human Resource Development through the Center for Healthcare Technology Development and by a grant of the Oriental Medicine R\&D Project, Ministry of Health and Welfare, Republic of Korea (no. 02-PJ9-PG3-20500-0009).

\section{References}

1. Nossal GJ, Herold KC and Goodnow CC: Autoimmune tolerance and type 1 (insulin-dependent) diabetes mellitus. Diabetologia 35 (suppl 2): 49-59, 1992.

2. Jorns A, Gunther A, Hedrich HJ, Wedekind D, Tiedge M and Lenzen S: Immune cell infiltration, cytokine expression, and Bcell apoptosis during the development of type 1 diabetes in the spontaneously diabetic LEW.1AR1/Ztm-iddm rat. Diabetes 54: 2041-2052, 2005.

3. Kanazawa Y, Komeda K, Sato S, Mori S, Akanuma K and Takaku F: Non-obese-diabetic mice: immune mechanisms of pancreatic B-cell destruction. Diabetologia 27 (suppl): 113-115, 1984.

4. Cetkovic-Cvrlje M and Eizirik DL: TNF-alpha and IFN-gamma potentiate the deleterious effects of IL- $1 \beta$ on mouse pancreatic islets mainly via generation of nitric oxide. Cytokine 6: 399406, 1994.

5. Eizirik DL, Flodstrom M, Karlsen AE and Welsh N: The harmony of the spheres: inducible nitric oxide synthase and related genes in pancreatic beta cells. Diabetologia 39: 875-890, 1996.

6. Kwon KB, Kim JH, Lee YR, Lee HY, Jeong YJ, Rho HW, Ryu DG, Park JW and Park BH: Amomum xanthoides extract prevents cytokine-induced cell death of RINm5F cells through the inhibition of nitric oxide formation. Life Sci 73: 181-191, 2003.

7. Corbett JA, Wang JL, Sweetland MA, Lancaster JR Jr and McDaniel ML: Interleukin $1 \beta$ induces the formation of nitric oxide by beta-cells purified from rodent islets of Langerhans. Evidence for the B-cell as a source and site of action of nitric oxide. J Clin Invest 90: 2384-2391, 1992.

8. Cunningham JM and Green IC: Cytokines, nitric oxide and insulin secreting cells. Growth Regul 4: 173-180, 1994.

9. Welsh N, Eizirik DL, Bendtzen K and Sandler S: Interleukin$1 \beta$-induced nitric oxide production in isolated rat pancreatic islets requires gene transcription and may lead to inhibition of the Krebs cycle enzyme aconitase. Endocrinology 129: 3167-3173, 1991.

10. Heitmeier MR, Scarim AL and Corbett JA: Interferon- $\gamma$ increases the sensitivity of islets of Langerhans for inducible nitric-oxide synthase expression induced by interleukin 1. J Biol Chem 272: 13697-13704, 1997.

11. Mandrup-Poulsen T: The role of interleukin-1 in the pathogenesis of IDDM. Diabetologia 39: 1005-1029, 1996.

12. Baeuerle PA and Henkel T: Function and activation of NFKB in the immune system. Annu Rev Immunol 12: 141-179, 1994.

13. Baldwin AS Jr: The NFKB and IкB proteins: new discoveries and insights. Annu Rev Immunol 14: 649-683, 1996.
14. Hong SH, Seo SH, Lee JH and Choi BT: The aqueous extract from Artemisia capillaris Thunb. inhibits lipopolysaccharideinduced inflammatory response through preventing NFKB activation in human hepatoma cell line and rat liver. Int J Mol Med 13: 717-720, 2004.

15. Kwon KB, Yang JY, Ryu DG, Rho HW, Kim JS, Park JW, Kim HR and Park BH: Vibrio vulnificus cytolysin induces superoxide anion-initiated apoptotic signaling pathway in human ECV304 cells. J Biol Chem 276: 47518-47523, 2001.

16. Moncada S, Palmer RM and Higgs EA: Nitric oxide: physiology, pathophysiology, and pharmacology. Pharmacol Rev 43: 109-142, 1991.

17. Green LC, Wagner DA, Glogowski J, Skipper PL, Wishnok JS and Tannenbaum SR: Analysis of nitrate, nitrite, and $\left[{ }^{15} \mathrm{~N}\right]$ nitrate in biological fluids. Anal Biochem 126: 131-138, 1982.

18. Park BH and Park JW: The protective effect of Amomum xanthoides extract against alloxan-induced diabetes through the suppression of NFKB activation. Exp Mol Med 33: 64-68, 2001.

19. Bradford MM: A rapid and sensitive method for the quantitation of microgram quantities of protein utilizing the principle of protein-dye binding. Anal Biochem 72: 248-254, 1976.

20. Kim HR, Rho HW, Park BH, Park JW, Kim JS, Kim UH and Chung MY: Role of $\mathrm{Ca}^{2+}$ in alloxan-induced pancreatic B-cell damage. Biochim Biophys Acta 1227: 87-91, 1994.

21. Park BH, Rho HW, Park JW, Cho CG, Kim JS, Chung HT and Kim HR: Protective mechanism of glucose against alloxaninduced pancreatic $\beta$-cell damage. Biochem Biophys Res Commun 210: 1-6, 1995.

22. Darville MI and Eizirik DL: Regulation by cytokines of the inducible nitric oxide synthase promoter in insulin-producing cells. Diabetologia 41: 1101-1108, 1998.

23. Lortz S, Tiedge M, Nachtwey T, Karlsen AE, Nerup J and Lenzen S: Protection of insulin-producing RINm5F cells against cytokine-mediated toxicity through overexpression of antioxidant enzymes. Diabetes 49: 1123-1130, 2000.

24. Vodovotz Y, Bogdan C, Paik J, Xie QW and Nathan C: Mechanisms of suppression of macrophage nitric oxide release by transforming growth factor B. J Exp Med 178: 605-613, 1993.

25. Amoah-Apraku B, Chandler LJ, Harrison JK, Tang SS, Ingelfinger JR and Guzman NJ: NFKB and transcriptional control of renal epithelial-inducible nitric oxide synthase. Kidney Int 48: 674-682, 1995.

26. Flodstrom $M$ and Eizirik DL: Interferon- $\gamma$-induced interferon regulatory factor-1 (IRF-1) expression in rodent and human islet cells precedes nitric oxide production. Endocrinology 138: 2747$2753,1997$.

27. Kwon KB, Kim EK, Jeong ES, Lee YH, Lee YR, Park JW, Ryu DG and Park BH: Cortex cinnamomi extract prevents streptozotocin- and cytokine-induced beta-cell damage by inhibiting NFKB. World J Gastroenterol 12: 4331-4337, 2006.

28. Kwon KB, Ryu DG, Shin MK, Shin BC, Hwang WJ, Lee YR, Park JW and Park BH: Fructus benincasae recens extract prevents cytokine-induced nitric oxide formation and cytotoxicity of RINm5F cells. Immunopharmacol Immunotoxicol 25: 615-625, 2003.

29. Evans JL, Goldfine ID, Maddux BA and Grodsky GM: Oxidative stress and stress-activated signaling pathways: a unifying hypothesis of type 2 diabetes. Endocr Rev 23: 599-622, 2002 .

30. Ho E and Bray TM: Antioxidants, NFKB activation, and diabetogenesis. Proc Soc Exp Biol Med 222: 205-213, 1999.

31. Ho E, Chen G and Bray TM: Supplementation of N-acetylcysteine inhibits NFKB activation and protects against alloxaninduced diabetes in CD-1 mice. FASEB J 13: 1845-1854, 1999.

32. Scarim AL, Heitmeier MR and Corbett JA: Heat shock inhibits cytokine-induced nitric oxide synthase expression by rat and human islets. Endocrinology 139: 5050-5057, 1998. 